\title{
Excavation of an Iron Age burial mound, Loch Borralie, Durness, Sutherland
}

\author{
by Gavin MacGregor \\ GUARD, University of Glasgow, Gregory Building, \\ Lilybank Gardens, Glasgow G12 8QQ \\ with contributions from \\ Adrian Cox, Michael Donnelly and Julie Roberts \\ illustrations by Caitlin Evans and John Arthur
}

Scottish Archaeological Internet Report 9, 2003

www.sair.org.uk 
Published by the Society of Antiquaries of Scotland, www.socantscot.org with Historic Scotland, www.historic-scotland.gov.uk

and the Council for British Archaeology, www.britarch.ac.uk

Editor Colin Wallace

Produced by Archetype Information Technology Ltd, www.archetype-it.com

ISBN: 0903903784

ISSN: $1473-3803$ 


\section{Contents}

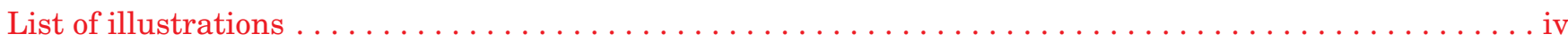

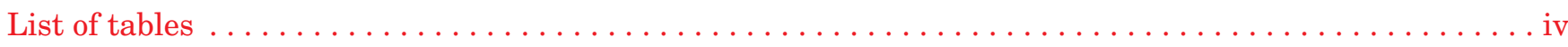

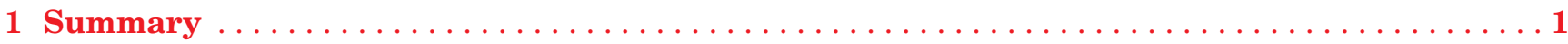

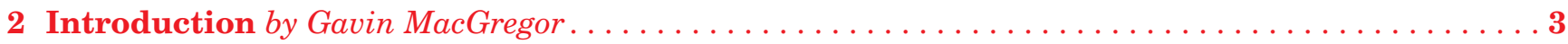

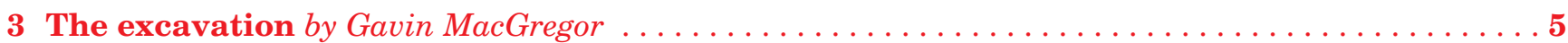

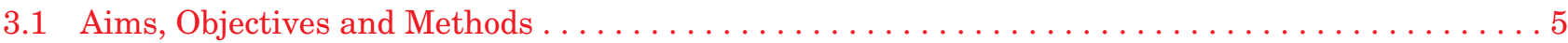

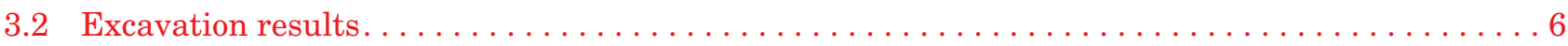

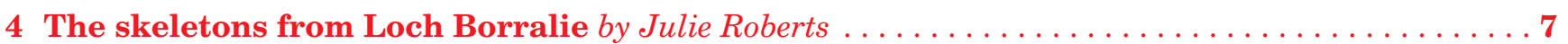

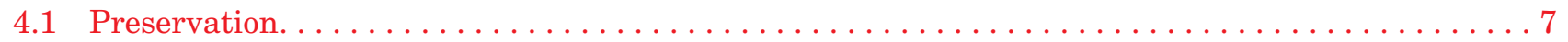

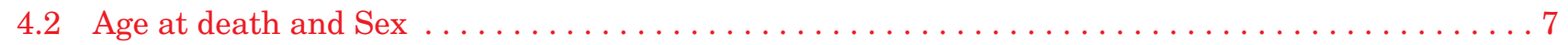

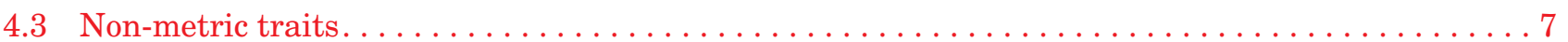

4.4 Health and Disease . . . . . . . . . . . . . . . . . . . . . . . . . . . . . . 7

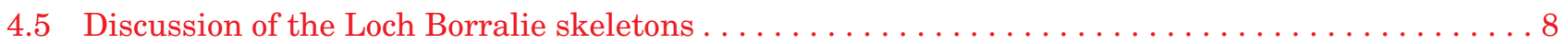

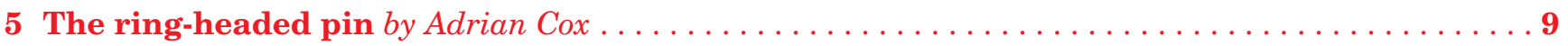

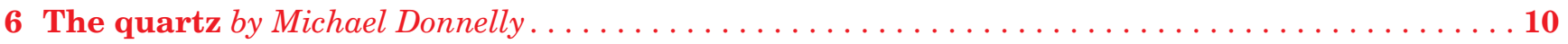

7 The radiocarbon date from Loch Borallie by Gavin MacGregor . . . . . . . . . . . . . . . 11

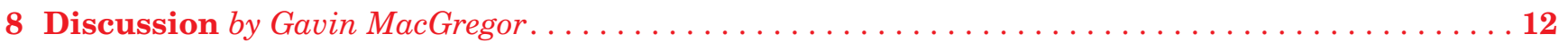

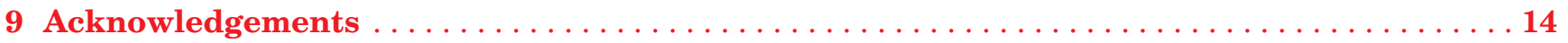

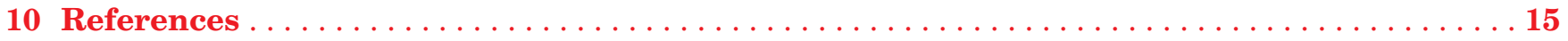

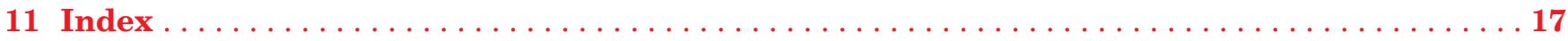




\section{List of illustrations}

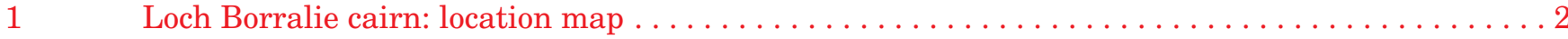

$2 \quad$ Loch Borralie cairn: a general view of the cairn and the quartzite outcrop . . . . . . . . . . 3

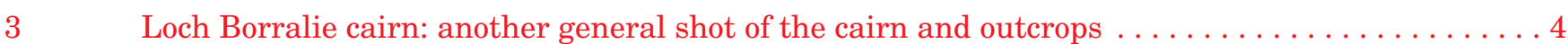

$4 \quad$ Loch Borralie cairn: plan of the excavation trench (inset: detailed plan of the burials) . . . . . . 5

$5 \quad$ Loch Borralie cairn: the ring headed pin $\ldots \ldots \ldots \ldots \ldots \ldots \ldots$

\section{List of tables}




\section{Summary}

As part of the Historic Scotland Human Remains Call Off Contract, Glasgow University Archaeological Research Division (GUARD) undertook an archaeological evaluation of the find spot of a human skull from a cairn at Loch Borralie, Sutherland (NGR NC 3790 6761). Excavation recovered the remains of two burials beneath the cairn and established that the cairn was multi-phased. One individual was an adult male (Skeleton 1), while the other was immature and of undeterminable sex (Skeleton 2). Both individuals showed signs of ill health, and dogs and/or rats appear to have gnawed their bones. A ring-headed pin was recovered close to Skeleton 1 during the excavation. A radiocarbon date was obtained from the left humerus of Skeleton 1 of 40 cal BC - cal AD 210 at 2 sigma (OxA-10253).

Excavation revealed that the cairn, broadly subrectangular in form, had a maximum height of $1.2 \mathrm{~m}$ and was composed of large, sub-angular and sub-rounded rocks (including quartz and quartzite) and occasional rounded cobbles within yelloworange sand. One inhumation, Skeleton 2, lay within an irregular grave, cut through the red brown sand that was sealed by the cairn and into the natural gravel sand below. The other inhumation, Skeleton 1 , was sealed by the red brown sand and had been placed on a low primary cairn of stone and earth, the full extent and depth of which remains unknown.

The tradition of extended inhumations within sub-rectangular cairns is a recognised funerary practice in the north of Britain during the first millennium AD. Many of these burials are generally considered to be Pictish in date, but Loch Borralie indicates that the tradition commenced in the Iron Age. There is increasing evidence for the variety of ways in which human remains were treated after death in the Iron Age, including cremations in re-used cists, single inhumations in graves and cists, multiple inhumations and the incorporation of human remains in 'domestic' contexts. The results of the excavation of the burial mound at Loch Borralie provide a useful addition to the range of mortuary and funerary rites which were practised during the Iron Age in Scotland. 

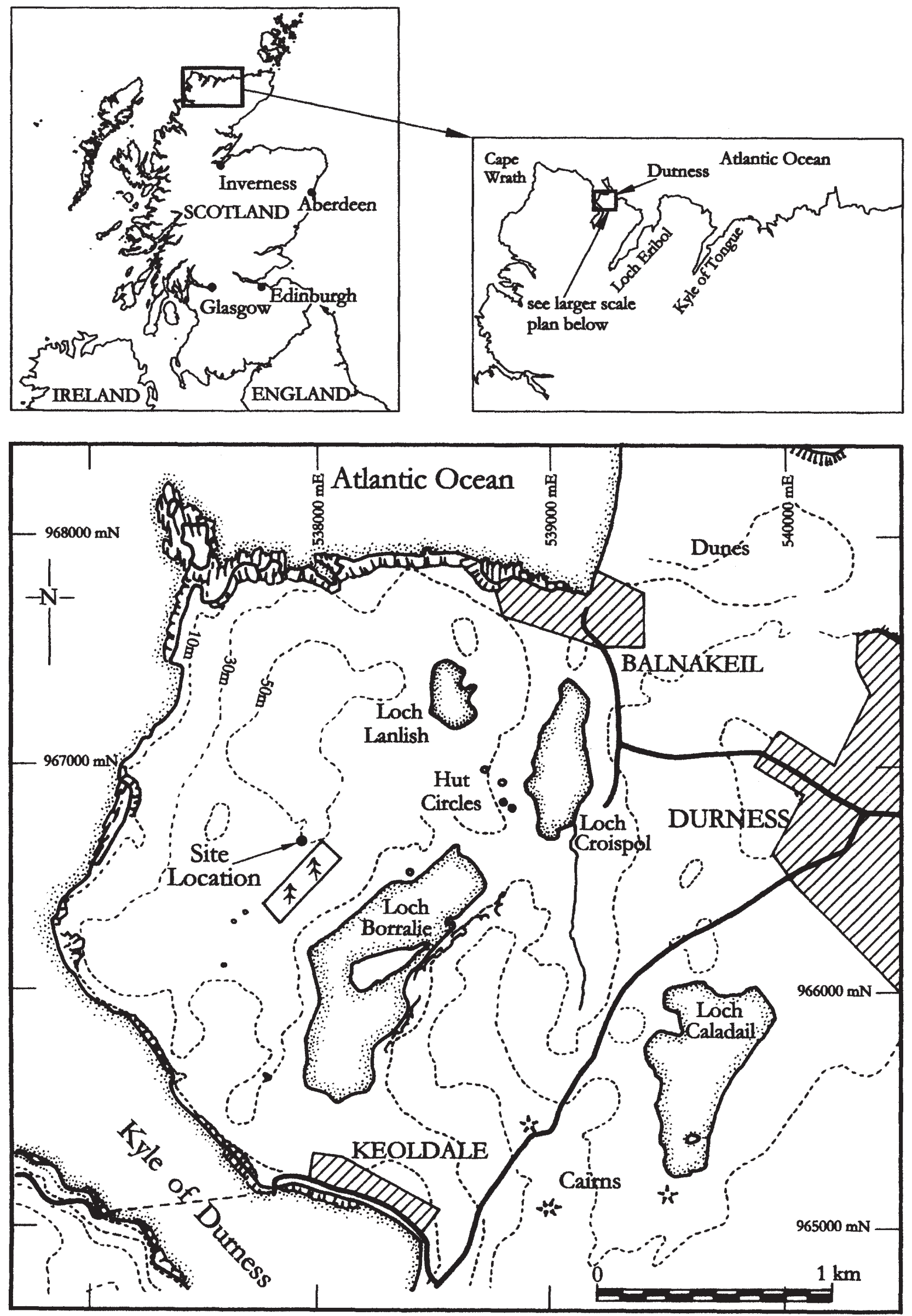

Illus 1 Loch Borralie cairn: location map 


\section{Introduction by Gavin MacGregor}

A human skull (now known to belong to the burial Skeleton 2: Section 4.1) was discovered in February 1998, apparently dislodged by burrowing rabbits from beneath a cairn at Loch Borralie, Sutherland. A visit by Historic Scotland led to the conclusion that the date and nature of the burial rite and its relationship to the cairn were unclear. It was possible that rabbit burrowing could disturb further human remains at the site, with an associated loss of archaeological information. This ultimately led to evaluation of the site being undertaken by Glasgow University Archaeological Research Division (GUARD) over two days during July 2000, as part of the Historic Scotland Human Remains Call Off Contract.

The site is located to the north of Durness (NGR NC 3790 6761) on a peninsula between the Kyle of Durness and Balnakeil Bay (Illus 1). The peninsula is characterised by undulating hill slopes with light, freely draining sandy soils and several large areas of sand erosion. The peninsula contains a significant number of archaeological remains, ranging from prehistoric to post-Medieval in date (Reid et al 1967;
Lelong and MacGregor forthcoming). In several areas of severe erosion, or deflated dunes, archaeological deposits can be temporarily revealed (Lelong and MacGregor 2002).

The cairn measures some $7 \mathrm{~m}$ north / south by 3.5 $\mathrm{m}$ east / west and is situated against a south-facing outcrop of quartzite (Illus 2). It is broadly sub-rectangular in form, but there is a notable arm to the cairn extending c $2.0 \mathrm{~m}$ up the slope. This may indicate that the cairn is partially buried by later deposits at its east side or is more complex in form (Illus 3). A later field dyke, badly denuded and tumbled, appears to have incorporated the southern edge of the cairn. Two small, low, circular kerbed cairns, c $1.0 \mathrm{~m}$ diameter, are located close by along the same contour (the nearest of which, context 003 , is shown on Illus 4).

The site archive has been sent to the National Monuments Record of Scotland, RCAHMS, Edinburgh. The finds have been allocated to Inverness Museum and Art Gallery by Historic Scotland's Finds Disposal Panel.

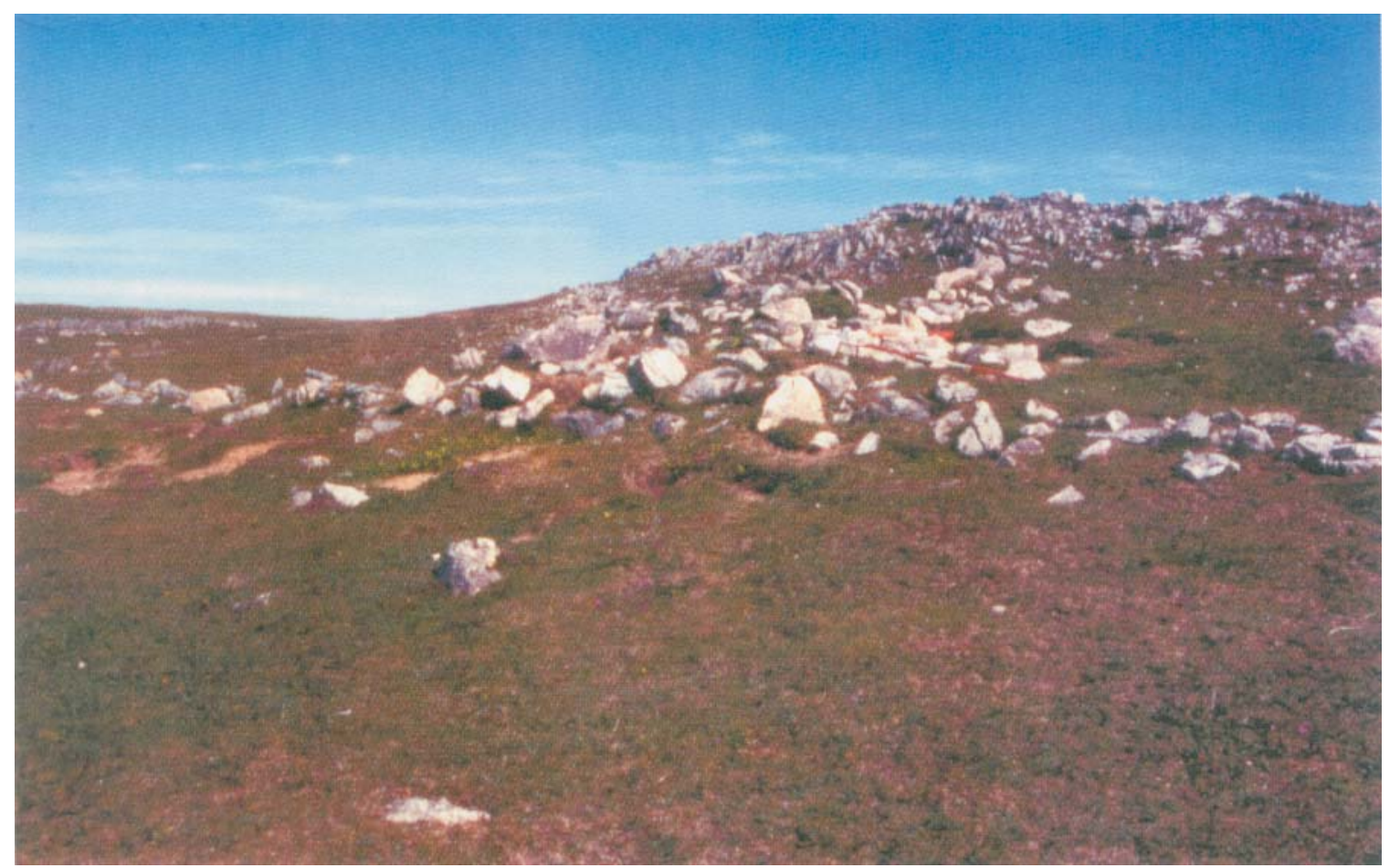

Illus 2 Loch Borralie cairn: a general view of the cairn and the quartzite outcrop 


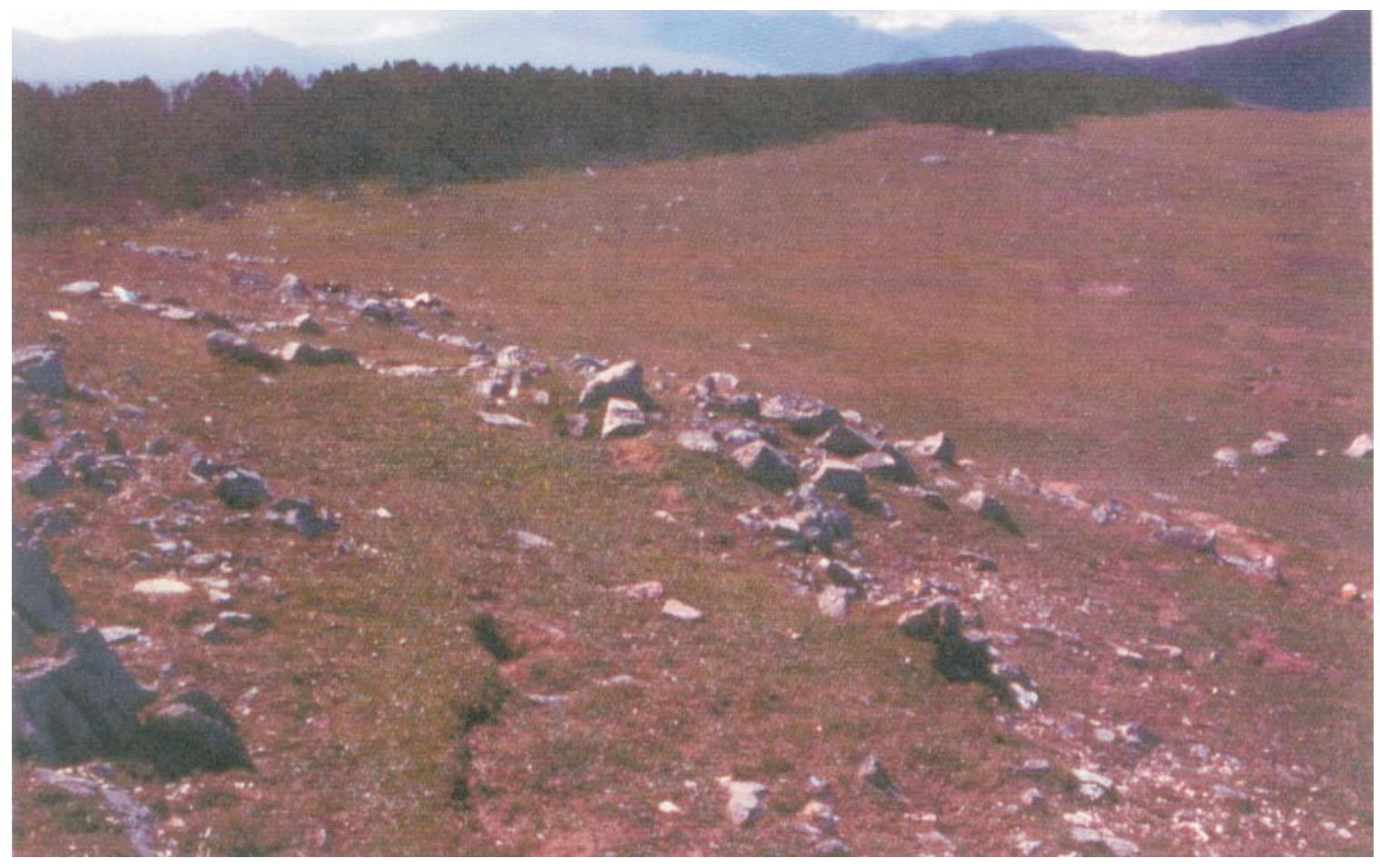

Illus 3 Loch Borralie cairn: another general shot of the cairn and outcrops 


\section{The Excavation by Gavin MacGregor}

\subsection{Aims, Objectives and Methods}

The evaluation of the site aimed to establish whether further human remains were present, how the human remains had been deposited at the site, the extent and number of cists or graves and the extent of the cairn. The work also aimed to establish whether there were any intimately related structures near to the site and to fully record and lift a limited number of cists/skeletons ( $c 1-3)$ if they were

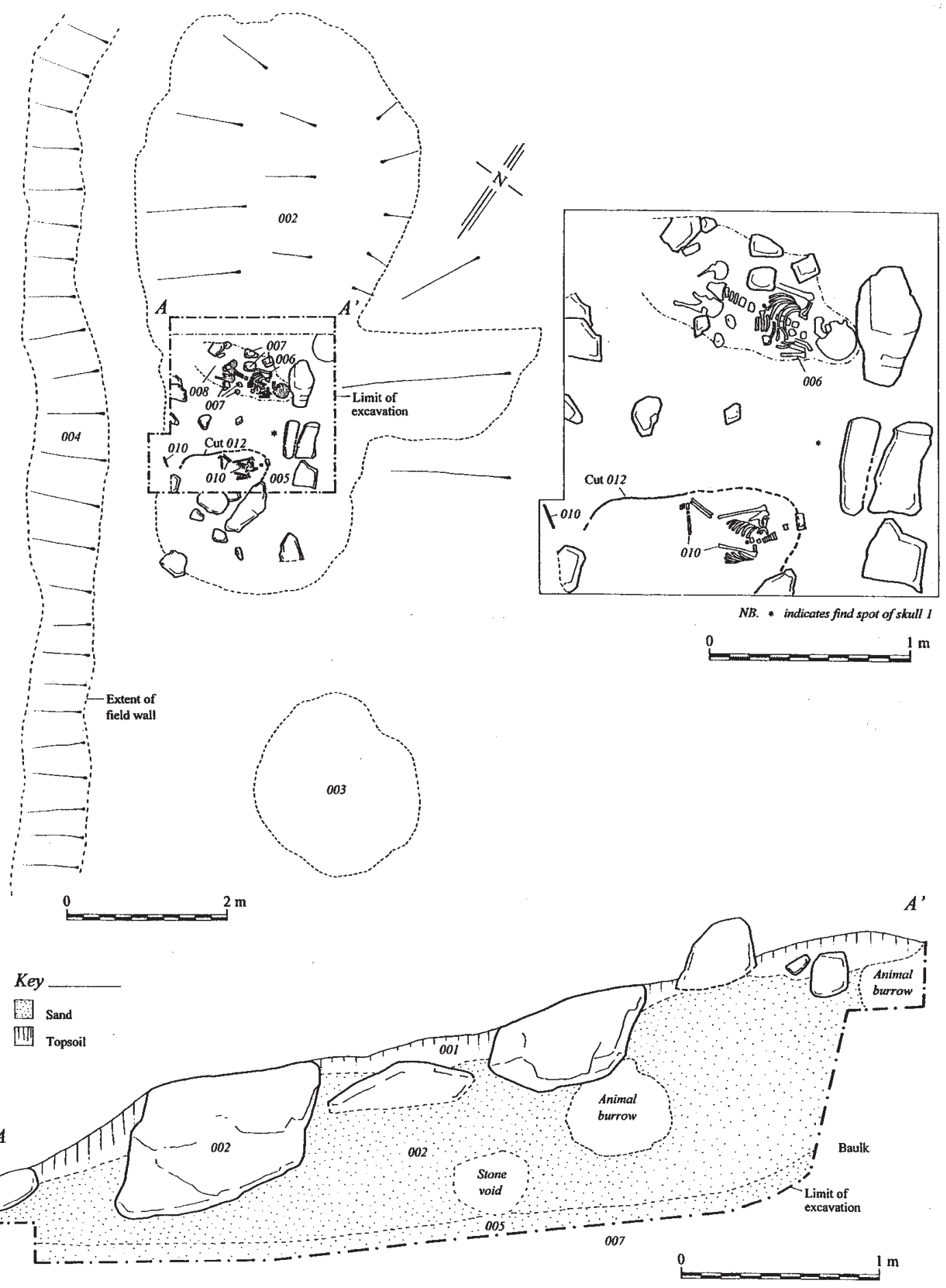

Illus 4 Loch Borralie cairn: plan of the excavation trench (inset: detailed plan of the burials) 
present. A trench measuring $2.1 \mathrm{~m}$ by $2 \mathrm{~m}$ was excavated by hand. Where they were present, turf and topsoil were removed and the stonework beneath cleaned and then recorded by measured plan. The remaining matrix of the cairn was then excavated to establish whether or not human remains were present. On completion of the excavation, the site was reinstated.

\subsection{Excavation results}

Excavation revealed that the cairn (context 002) had a maximum height of $1.2 \mathrm{~m}$ and was composed of large, sub-angular and sub-rounded rocks (including quartz and quartzite) and occasional rounded cobbles within yellow-orange sand. The cairn sealed a layer of red brown sand (005) up to $0.20 \mathrm{~m}$ in depth. Further excavation revealed the remains of two inhumations (Illus 4). Both were supine and lay east to west with their heads at the east end. An iron ring-headed pin (small find no 1) was recovered during the excavation of the red brown sand (005), lying $0.15 \mathrm{~m}$ to the north of Skeleton 1 (Section 5).

One inhumation, Skeleton 2 (context 010), lay within an irregular grave (012), cut through the red brown sand (005) and onto the natural gravel sand (013) below. The grave had been filled with sand (011) and a small stone had been placed immediately to the north-east of the head. This individual was poorly preserved; the lower limbs had decayed almost completely and were found to be disarticulated. Analysis has established that this individual was aged between 12 and 18 years and consequently of indeterminable sex (see Section 4.2).

The other inhumation, Skeleton 1 (context 006), was sealed by the red brown sand (005: note that the line near the section line on Illus 4 marks only the extent to which this deposit was excavated to reveal the skeleton). Skeleton 1 was relatively well preserved, apart from the almost complete absence of limbs; only the upper half of the left femur and upper half of both humeri were present. This skeleton, of a small, shortly-built male of middle age or older (Section 4.2) had been placed on a low cairn (007/008) of stone and earth. Two pieces of probably struck quartz (small finds 2 and 3: Section 6) were found beneath Skeleton 1. A large stone had been placed immediately to the east of the person's head. The full extent and depth of the primary cairn (007) remains unknown. It did, however, appear to sit on a natural deposit of gravel sand (013). 


\section{The skeletons from Loch Borralie by Julie Roberts}

The remains of possibly three individuals were received for analysis. However, those recovered in 1998 (a skull) were found to belong to the excavated burial Skeleton 2 and are discussed below as part of this burial.

\subsection{Preservation}

Skeleton 1 was approximately 50\% complete. The right and left tibia, fibula and feet were entirely missing, as was the right femur with the exception of the proximal end, which was lodged in the acetabulum. The right clavicle, left radius and left hand, and the facial bones (right and left zygoma, nasal bones, and maxilla) were also missing. All of the surviving long bones had been broken around the mid-shaft region, and there was evidence of gnawing by rodents at the fractured ends. There was also gnawing of the menton (the chin) on the anterior surface.

Skeleton 2 (incorporating the earlier find of a skull) was approximately $25 \%$ complete. The left scapula, clavicle, radius, pelvis, femur, fibula, foot and most of the hand were missing entirely, as were the sternum, sacrum, right fibula and foot. Only a small fragment of the right ilium was present, and the surviving piece of femur could not be attributed to either side. Again, there was severe surface erosion of the bones, and many were split longitudinally. There was possible evidence of gnawing by rodents at the ends of the humeri and tibial fragments, but no mid-shaft breakage as seen in Skeleton 1.

\subsection{Age at Death and Sex}

Skeleton 1 had reached dental and skeletal maturity, and the auricular surface of the ilium indicated an age of between 45 and 60 years. The degenerative changes present in the spine were also consistent with an age at death greater than 45 years. The bones of Skeleton 1 were extremely small and gracile and, on the basis of size alone, looked more female than male. The sexually dimorphic features of the pelvis, sacrum, and cranium were, however, all male. The impression they gave, therefore, was of a small, slightly built male, of middle age or older.

Skeleton 2 was immature; therefore, a more precise age could not be determined. Analysis of the dentition has indicated an age at death of 15 years \pm 36 months. In addition, the epiphyses of the humerus and scapula had not fused, suggesting an age of less than 15 to 18 years at death. Also, as Skeleton 2 was an immature individual, the sex could not be estimated.

\subsection{Non-metric traits}

Non-metric traits are not generally recorded on immature individuals, as skeletal development is not complete. In this instance, however, the presence of a metopic suture in the younger individual was recorded, as this particular trait has in the past been associated both with specific population groups and metabolic disorders (Bruce 2000, 300-01). Bridging of the right and left supra-orbital notch was also recorded in this individual, as it was observed in Skeleton 1. In addition to the bridged supra-orbital notches, Skeleton 1 had an extra-sutural mastoid foramen on the left side, and a lateral flange on the surviving femur. The latter is likely to be related to musculature and physical activity.

\subsection{Health and Disease}

The evidence was that Skeleton 1 had suffered from osteoarthritis of the spine and iron deficiency anaemia. Skeleton 2 had suffered from possible scurvy and secondary arthritis of the cervical spine. Both individuals had suffered from different types of oral pathology.

The adult male (Skeleton 1) had also suffered from iron deficiency anaemia of moderate severity, characterised by Cribra Orbitalia (lesions in the roofs of the orbits). There are many causes of iron deficiency anaemia, among the most common being lack of absorbable iron in the diet and a high pathogen load within the body (Grauer 1991). The disease, in this instance, may have caused a general feeling of fatigue and malaise, but it was probably of insufficient severity to cause the more extreme manifestations of breathlessness and palpitations.

Skeleton 2 had suffered from a different type of metabolic disorder - scurvy, a condition caused by prolonged, inadequate intake of vitamin $\mathrm{C}$ (Ortner and Putschar 1981). The resultant weakening of the blood vessels can cause sub-periosteal haemorrhaging, commonly on the orbital roofs and at the metaphyses of the long bones. Due to the poor state of preservation of Skeleton 2, and in particular the absence of the ends of the long bones, differential diagnosis of the condition was difficult. The presence of new bone formation in the orbits was, however, suggestive of scurvy.

This individual also suffered from dental enamel 
hypoplasia (DEH) and it is possible that the two conditions were linked. $\mathrm{DEH}$ is the name given to the defects that appear in the enamel of the teeth, representing a cessation in growth and development. They are considered to be indicators of physiological stress, and febrile infections, malnutrition and metabolic disorders during childhood have all been cited as possible causes (Aufderheide and Rodriguez-Martin 1998). The condition was evident on all the maxillary incisors, the mandibular and maxillary canines and the right mandibular third molar of Skeleton 2.

Skeleton 1 had experienced ante-mortem loss of both mandibular first molars and second pre-molars. A common cause of this is the formation of plaque and it occurs due to poor oral hygiene.

\subsection{Discussion of the Loch Borralie skeletons}

The amount of surface erosion present and the weathering of the bones suggested that, although both individuals were recovered from formal graves, their remains had at some point lain exposed above the ground. The breakage of the long bones in Skeleton 1 and the gnawing evident on the bones of both individuals would also support this interpretation. The fracture patterns observed in Skeleton 1 were characteristic of damage caused by carnivores such as dogs and wolves, the shafts of the long bones having been broken in order to obtain marrow (Brain 1981).

The gnawing of the ends of the long bones in both skeletons was most likely the work of rats. The reason for the exposure of the bodies before formal burial is unclear. It is possible that the individuals died during the winter months and were left unburied until the spring because the earth was too hard and frozen for graves to be dug. It is also possible that these individuals had been left after death somewhere safe, in a cave perhaps, until the ground was soft enough to bury them, and that they had unfortunately been discovered and mauled by animals.

The role of excarnation in the Iron Age has previously been discussed in relation to the evidence from Central Southern Britain (Carr and Knüsel 1997). That review of the evidence supports the contention that excarnation and secondary burial rites were practiced during this period. Carr and Knüsel suggest four major indicators of excarnation: animal gnawing on bones; scattered, isolated, fragmentary, weathered or splintered bones; disarticulated skeletons; incomplete skeletons lacking a limb, phalanges or other parts (Carr and Knüsel 1997, 170). In the case of the burials from Loch Borralie, at least three of the major indicators are present and as such would support the interpretation that some form of purposeful exposure of the bodies took place prior to burial beneath the cairn.

Another interesting feature of the burials was the general ill-health of the two individuals. Both had suffered from nutritional disorders that may have been the result of dietary deficiencies or endemic infection. The poor state of preservation of the remains meant that a true assessment of skeletal pathology could not be made, but the available evidence is suggestive of individuals that were physiologically stressed. Analysis of more burials from this group would be required in order to determine whether this applied to the community as a whole. 


\section{The ring-headed pin by Adrian Cox}

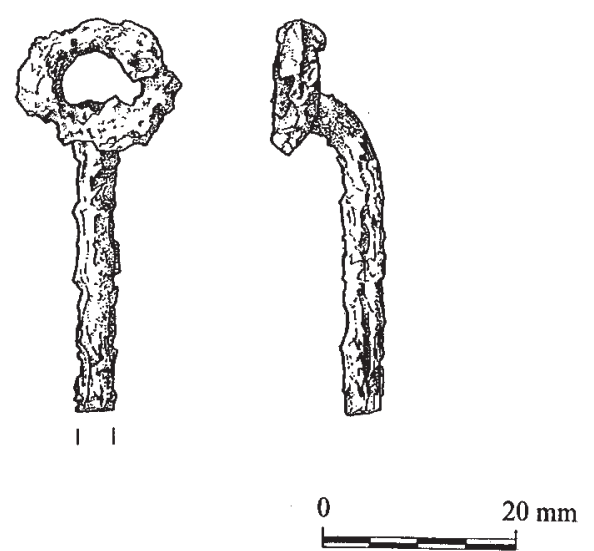

Illus 5 Loch Borralie cairn: the ring headed pin

An iron ring-headed pin (Illus 5) was recovered from the deposit of red-brown sand (005), under cairn material (002: Section 3.2). Ring-headed pins were used to fasten garments, in conjunction with a thread wound around the shaft and tied to the head. Many excavated examples are of copper alloy, either cast in a single piece or fashioned from wire, but iron examples are known.

It is a projecting ring-headed pin with a plain, circular head and a circular or oval cross-sectioned shaft. The shaft is broken at a point $29 \mathrm{~mm}$ below the lowest part of the head. Surviving length $40 \mathrm{~mm}$; diameter of head (disregarding corrosion products) $13 \mathrm{~mm}$; thickness of shaft $4 \mathrm{~mm}$ (context 005; Find No 1).

Stevenson noted the possibility of the projecting ring-headed pins being a native development, although influenced by the design of Late Bronze
Age sunflower pins, and suggested a date-range between the second and third centuries $\mathrm{AD}$ for this type, although an earlier date is not ruled out (Stevenson 1955, 288). Two copper-alloy pins with projecting ring heads were recovered from the Crosskirk broch site in Caithness, and dates in the second century BC were suggested for these (Fairhurst 1984, 116). Examples excavated at Howe, Orkney are from contexts dating around the second century BC to the fourth century AD (Ballin Smith 1994, 222).

More recent excavations have produced both late and early dating evidence for the type. At Scalloway, a copper alloy ring-headed pin was recovered from the phase 1 occupation of the broch, which was sealed by a destruction event radiocarbon-dated to cal AD345-505 (Sharples 1998, 29-30). Further afield, a wire-type, iron ring-headed pin came from the fire-destruction deposit on the floor of the Middle Iron Age roundhouse at South Shields (Croom 2002, 141-43), a context dated 390-170 cal BC.

Other examples of similar, wire-type, iron ring-headed pins have been recovered from graves at Moredun and Boysack Mills. At Moredun a cist contained a crouched inhumation accompanied by a ring-headed pin, an iron pennanular brooch and an iron dolphin brooch (Coles 1904; Close-Brooks 1984, 89). Another ring-headed pin was recovered from the central grave within a square-ditched barrow at Boysack Mills, Angus (Murray and Ralston 1997, illus 9). That pin appears to have accompanied a supine inhumation orientated south-east to northwest. The radiocarbon dates from the Boysack Mills grave, however, appear to relate to later activity in the early part of the second millennium $\mathrm{AD}$ and consequently the date of the burial was unclear. 


\section{The quartz by Michael Donnelly}

Two pieces of quartz (small finds 2 and 3) were recovered from below Skeleton 1 (primary cairn, context 007: Section 3.2). Both are pieces of tabular, opaque, milky quartz with occasional purplish veins. One (small find 2) displays areas of damage along two of its edges that may relate to crude retouch and/or extensive use. This piece also has a possible bulbar area, although it is difficult to be exact in this identification in tabular quartz. The second piece is less convincing as a worked item; however, if the first example is genuine, then the possibility that the second has also been struck must be considered. Overall, small find 2 may be deemed to be a probable example of struck quartz, while small find 3 would only be considered as a possible.

Small find 2 is a probable regular quartz flake, $31 \mathrm{~mm} \times 22 \mathrm{~mm} \times 13 \mathrm{~mm}$, with possible retouch/ damage along its dorsal distal and ventral right margins, possible highly prominent tabular bulbar cone and indication of two or more possible uniplane removals. Small find 3 is a possible irregular quartz flake, $21 \mathrm{~mm} \times 14 \mathrm{~mm} \times 6 \mathrm{~mm}$, possibly snapped distally, with indications of two or more possible uniplane removals.

The use of inferior quartz types is known from Scotland and other countries (Alakärppä et al 1998; Bang-Anderson 1998). While certain types of quartz will display telltale signs of knapping, such as bulbs of percussion, radial fissuring, negative removal scars on the dorsal surface, etc., other types will not. At Ben Lawers on Loch Tayside (Atkinson et al forthcoming), a Mesolithic cache of low-quality quartz was found in a pit alongside an assemblage containing flint and several types of quartz that split with a conchoidal fracture (as opposed to tabular). Thus in Scotland, even supposedly inferior quartz can find itself being prized for reasons unknown (possibly having a ritual or symbolic relevance: see Darvill 2002). 


\section{The radiocarbon date from Loch Borallie by Gavin MacGregor}

The left humerus from Skeleton 1 was sent for C-14 dating at the Oxford Radiocarbon Accelerator Unit. The date obtained suggests the individual lived during the first quarter of the first millennium AD. The date was calibrated using OxCal v3.5.

At the time, no request for a date from a sample from Skeleton 2 was submitted due to the poor preservation of the bones and the possibility that no collagen survived. When the cairn has been demonstrated by excavation to be multi-phase (Section 3.2) and the two burials were clearly stratigraphically separate, with hindsight it is perhaps regrettable that only a single radiocarbon date was obtained for them. It could be argued that as the dated skeleton (Skeleton 1) predated the cairn, the suggestion in Section 8 that rectangular cairns can be pre-Pictish is not substantiated, but the evidence observed during excavation does not support an extended dating (as opposed to phasing) for the sequence of burials and cairn-building.

Table 1 The radiocarbon date from Loch Borralie

\begin{tabular}{llcccc}
\hline Lab Code & Sample Material & Lab. Age BP & $\delta$ C13 & Calibrated 1 sigma & dates 2 sigma \\
\hline OxA-10253 & $\begin{array}{l}\text { Homo Sapiens Left } \\
\text { humerus, Skeleton 1 }\end{array}$ & $1931 \pm 37$ & -20.2 & AD 25 -130 & 40 BC - AD 210 \\
\hline
\end{tabular}




\section{Discussion by Gavin MacGregor}

The archaeological evaluation established that the find spot of the skull (now seen to be part of Skeleton 2 ) was a cairn (Illus 4), with several phases to its construction and use, containing inhumations orientated east to west (Section 3.2). The earliest identifiable phase of activity involved the construction of a low primary cairn (context 007/008). This was followed by the burial of Skeleton 1 on this cairn, which was then sealed by a layer of clean sand (005). Later, Skeleton 2 was buried in an irregular grave cut through the sand layer 005 . The relatively clean and uniform nature of sand layer 005 would suggest that this sequence of events took place over a short timespan. Both burials were, however, ultimately sealed by a larger cairn (002). It is probable that further burials are present within the remainder of the cairn, which extended outside the excavation trench. Radiocarbon dating on Skeleton 1 (Section 7) indicates that the burial mound was probably in use during the first quarter of the first millennium $\mathrm{AD}$.

It is probable that the individuals buried at Borralie lived in nearby settlements on the headland, where examples of hut circles and a possible dun are present, which probably date to the Iron Age (Reid et al 1967; Lelong and MacGregor forthcoming). Analysis of both skeletons has shown their general state of ill health (Section 4.4). It is difficult to generalise from just the two individuals from the Borralie mound, but this suggests that the population of the area may have been under stress at the time, perhaps through factors such as population pressure or several seasons of poor harvests.

Of particular note about the individuals buried was the absence or incompleteness of several major limbs. Roberts has discussed above the possibility that this may relate to dogs initially having gnawed the bones and suggested that a tradition of spring burial may have resulted in the exposure of the bodies to dogs (Section 4.5). The possibility has also to be considered that this may have been the result of deliberate excarnation before burial (cf Armit 1997, 96; Bristow 1998, 158; Carr and Knüsel 1997).

The tradition of extended inhumations within sub-rectangular cairns is a recognised funerary practice in the north of Britain during the first millennium AD (Ashmore 1981; Close-Brooks 1984). Many of these burials are generally considered to be Pictish in date, but the results of the excavation at Loch Borralie indicates that the tradition commenced in the Iron Age.

The form of monument and burial rite at Loch Borralie can be compared with that at Gullane, East Lothian (Ewart and Curle 1908). The monument at Gullane comprised an irregular oval measuring $c 6 \mathrm{~m}$ by $4 \mathrm{~m}$. The mound sealed a minimum of six skeletons that were not in cists and at least one skeleton was orientated east to west. A spiral ring of bronze and an iron knife or dagger were found accompanying the burials. In contrast, many of the burials in other sub-rectangular cairns were within cists e.g. at Ackergill, Caithness (Edwards 1926) and Dunrobin, Sutherland (Close-Brooks 1981) or graves e.g. at Sandwick, Shetland (Bigelow 1980) and generally appear to be of a single phase. It is possible, therefore, that Loch Borralie and Gullane stand for a form of cemetery mound dating to the late first millennium $\mathrm{BC}$ or early first millennium $\mathrm{AD}$ that represents the precursor to later, sub-rectangular cairns containing single graves or cists.

It is of note that the ring-headed pin found at Loch Borralie (Section 5) was almost certainly a deliberate deposit with one of the burials. Its close proximity to Skeleton 1 may suggest that it relates to this burial, but as it was recovered during the excavation of the clean sand (005) above the primary cairn it may have been carried downwards from the later Skeleton 2 through burrowing.

The variety of Iron Age burial traditions suggests, however, that different people within society were accorded different burial rites, perhaps relating to status, gender or age groups. Many of the variations in burial rite may not, therefore, represent chronological distinctions but rather differences in social practices. Just as there are differences in the form of burial rite, there are also distinctions in how that burial rite was performed as indicated by choices in grave goods that accompanied burials. In broad terms, we could conceive of three main classes of burial as suggested by their grave goods: those that are accompanied by personal ornaments (examples in Section 5), those that also have weapons (Hunter forthcoming: e.g. the double inhumation in a cist accompanied by a sword and spears at Camelon [Breeze, Close-Brooks and Ritchie 1976] or the single inhumation in a cist accompanied by a sword at Marshill, Alloa [Paul Duffy, pers comm]) and those burials that are unaccompanied. Consequently, the variability in burial rite and selection of grave goods presents a potentially complex system of signification that may relate to the role or status of the individuals.

There is increasing evidence for the variety of ways in which human remains were treated after death in the Iron Age, including cremations in re-used cists (Ritchie and Thornber 1988), single inhumations in graves and cists, multiple inhumations (Longworth et al 1967; Crone 1992), possible bog bodies (Cowie et al 2002), cave burials (Armit 1997, 91) and the incorporation of human remains in 'domestic' contexts (e.g. Armit 1997, 98-99). In each case, the extended 
nature of funerary and mortuary rites, which may include exposure or excarnation of the body as suggested by the Borralie burials, is a factor that requires to be considered during their interpretation (e.g. Pearce 1997). Consequently, the results of the excavation of the burial mound at Loch Borralie provide a useful addition to the range of mortuary and funerary rites which were in practice during the Iron Age in Scotland. 


\section{Acknowledgements}

The fieldwork was undertaken with the assistance of Paul Duffy. Many thanks to Keoldale Sheep Stock Club for permission to excavate on the land. The site was discovered by Nicholas Powell and assistance was kindly given by Hugh Powell. The project was specified and funded through to publication by Historic Scotland and was monitored by Alison Fox on behalf of Highland Council. The project was managed for GUARD by Beverley Ballin-Smith and the report was copy-edited by Olivia Lelong. Caitlin Evans and John Arthur prepared the illustrations. The anonymous referee and the SAIR Editor are thanked for their comments on the text. 


\section{References}

Alakärppä J, Ojanlavta, E and Ylimaunu, T 1998 'Raw material sources and use of quartz in the Kemi-Tornio area in the north of the Gulf of Bothnia', in Holm, L and Knuttson, K (eds.) [below], 5-21.

Armit, I 1997 Celtic Scotland. London.

Ashmore, P J 1981 'Low cairns, long cists and symbol stones', Proc Soc Antiq Scot 110, (1978-80), 346-55.

Atkinson, J A, Donnelly, M, Lelong, O and MacGregor, G forthcoming Ben Lawers Historic Landscape Project: the pilot seasons, 1996-1998 [ = Tayside Fife Archaeol Committee monograph series].

Aufderheide, A C and Rodriguez-Martin, C 1998 The Cambridge Encyclopaedia of Human Palaeopathology. Cambridge.

Ballin Smith, B (ed.) 1994 Howe: Four millennia of Orkney prehistory - Excavations 1978-1982. Edinburgh. [ = Soc Antiq Scot Monograph 9].

Bang-Anderson, S 1998 'Why all these white and shiny stones? On the occurrence of non-flint lithic material on Mesolithic inland sites in south-western Norway', in Holm, L and Knuttson, K (eds.) [below], 39-54.

Bigelow, G 1980 'Sandwick, late-Norse settlement, pre-Norse burials', Discovery and Excavation in Scotland, 1980, 26-27.

Brain, C K 1981 The Hunters or the Hunted? An Introduction to African Cave Taphonomy. Chicago.

Breeze, D J Close-Brooks, J and Ritchie, J N G 1976 'Soldiers' burials at Camelon, Stirlingshire, 1922 and 1975', Britannia 7 (1976), 73-95.

Bristow, P H W 1998 Attitudes to disposal of the dead in southern Britain 3500bc-AD43. Oxford. [ = British Archaeological Reports British Series 274].

Bruce, M 2000 'The human remains', in Perry, D R Castle Park, Dunbar Two Thousand Years on a Fortified Headland, 295-311. Edinburgh. [ = Soc Antiq Scot Monograph 16].

Carr, G \& Knüsel, C 1997 'The ritual framework of excarnation by exposure as the mortuary practice of the early and middle Iron Ages of central southern Britain', in Gwilt, A and Haselgrove, C (eds.) [below], 167-73.

Close-Brooks, J 1981 'Excavations in the Dairy Park, Dunrobin, Sutherland, 1977', Proc Soc Antiq Scot 110 (1978-80), 328-45.

Close-Brooks, J 1984 'Pictish and other burials', in Friel, J G P and Watson, W G (eds) Pictish studies: settlement, burial and art in Dark Age Northern Britain, 87-114. Oxford [ =
British Archaeological Reports British Series 125].

Coles, F R 1904 'Notice of the discovery of a cist of the Early Iron Age, on the estate of Moredun, near Gilmerton', Proc Soc Antiq Scot 38 (1903-04), 427-38.

Cowie, T, Wallace, C and Pickin, J 2002 'Bog bodies from Scotland: redrawing the map', NewsWARP 30 (2002), 14-22.

Crone, B A 1992 'An Iron Age cist at North Belton Farm, Dunbar', Proc Soc Antiq Scot 122 (1992), $161-70$

Croom, A T 2002 'The Iron-Age Finds', pp141-47 of Hodgson, N Stobbs, G C and Van der Veen, M 'An Iron-Age Settlement and Remains of Earlier Prehistoric Date beneath South Shields Roman Fort, Tyne and Wear', Archaeol Journal 158 (2001), 62-160.

Darvill, T 2002 'White on Blonde: Quartz Pebbles and the Use of Quartz at Neolithic Monuments in the Isle of Man and Beyond', in Jones, A and MacGregor, G (eds.) Colouring The Past: The Significance of Colour in Archaeological Research, 73-91. Oxford.

Edwards, A J H 1926 'Excavation of a number of graves in a mound at Ackergill, Caithness', Proc Soc Antiq Scot 60 (1925-6), 160-82.

Ewart, E and Curle, A O 1908 'Notice of the examination of a cairn and interments of the Early Iron Age at the Black Rocks, Gullane, Haddingtonshire, on 14th March 1908', Proc Soc Antiq Scot 42 (1907-8), 332-36.

Fairhurst, H 1984 Excavations at Crosskirk Broch, Caithness. Edinburgh. [ = Soc Antiq Scot Monograph 3].

Grauer, A L 1993 'Patterns of Anaemia and Infection from Medieval York, England', American Journal of Physical Anthropology 91 (1993), 203-13.

Gwilt, A and Haselgrove, C (eds.) 1997 Reconstructing Iron Age Societies New approaches to the British Iron Age. Oxford [ = Oxbow Monograph 71].

Holm, L and Knuttson, K (eds.) 1998 Social Interpretation in Lithic Analyses: Proceedings from the Third Flint Alternatives Conference at Uppsala, Sweden, October 18-20 1996. Uppsala [ = Occasional Papers in Archaeology 16].

Hunter, $\mathrm{F}$ forthcoming 'The image of the warrior coin iconography in context', in Haselgrove, $\mathrm{C}$ and Wigg, D (eds.) Ritual and Iron Age Coinage in North West Europe. Frankfurt.

Lelong, O and MacGregor, G 2002 Loch Borralie Survey, Glasgow [ = GUARD report 950].

Lelong, $\mathrm{O}$ and MacGregor, $\mathrm{G}$ forthcoming 'Gallant 
Country of Corn: making sense of a

multi-period landscape on the Kyle of Durness, Sutherland', in Carver, E and Lelong, O (eds.) Modern Views, Ancient Lands: New Working Thought on Cultural Landscapes. Oxford (to be published by Archaeopress).

Longworth, I H, Brothwell, DR and Powers, R 1967 'A Massive Cist with Multiple Burials of Iron Age Date at Lochend, Dunbar', Proc Soc Antiq Scot 98 (1964-66), 173-98.

Murray, D and Ralston, I 1997 'The excavation of a square-ditched barrow and other cropmarks at Boysack Mills, Inverkeilor, Angus', Proc Soc Antiq Scot 127 (1997), 359-86.

Ortner, D J and Putschar, W G J 1981 Identification of Palaeopathological
Conditions in Human Skeletal Remains. Washington DC.

Pearce, J 1997 'Death and time: the structure of Iron Age mortuary ritual', in Gwilt, A and Haselgrove, C (eds.) [above], 174-80.

Reid, R W K, David, G and Aitken, A 1967 'Prehistoric Settlement in Durness', Proc Soc Antiq Scot 99 (1966-7), 21-35.

Ritchie, J N G and Thornber, I 1988 'Cairn 3, Acharn, Morvern, Argyll', Proc Soc Antiq Scot 118 (1988), 95-98.

Sharples, N M 1998 Scalloway: a broch, late Iron Age settlement and medieval cemetery in Shetland. Oxford [ = Oxbow Monograph 82].

Stevenson, R B K 1955 'Pins and the chronology of brochs', Proc Prehist Soc 21 (1955), 282-94. 


\section{Index}

Human remains

age \& sex (adult male [sk 1], immature [sk 2]) 7

damage (carnivores and rodents) 7-8

non-metric traits 7

pathology (dental enamel hypoplasia, iron deficiency anaemia, osteoarthritis, scurvy [possible]) 7-8

preservation (exposure or excarnation) 7-8

\section{Iron Age burials}

Boysack Mills, Angus 9

exposure or excarnation of the body 8, 12

extended inhumations within sub-rectangular cairns 12

Gullane, East Lothian 12

Moredun Estate, Gilmerton 9 variety of burial traditions $12-13$

with ring-headed pins 9

\section{Loch Borralie, Durness}

cairn, sub-rectangular 3, 5-6

grave-goods, probable 9, 12

ill-health of Iron Age population 7-8, 12

Iron Age inhumation burials, multi-phase 6

Iron Age settlements 12

radiocarbon date 11

Lithics (inferior struck quartz) 10

Ring-headed pins, iron

dating 9

from Borralie cairn 6, 9, 12

from burials 9 